\title{
Characterization of Betabel Extract (Beta vulgaris) Encapsulated with Maltodextrin and Inulin
}

\author{
Martha A. Flores-Mancha ${ }^{1}$, Martha G. Ruíz-Gutiérrez ${ }^{2}$, Rogelio Sánchez-Vega ${ }^{1}$, \\ Eduardo Santellano-Estrada ${ }^{1}$ (D) and América Chávez-Martínez ${ }^{1 \text {,* }}$ \\ 1 Departamento de Tecnología de Productos de Origen Animal, Facultad de Zootecnia y Ecología, \\ Universidad Autónoma de Chihuahua, Periférico Francisco R. Almada km 1. Chihuahua, Chih 33820, \\ Mexico; 99azu.flores@gmail.com (M.A.F.-M.); rsanchezv@uach.mx (R.S.-V.); esantellano@uach.mx (E.S.-E.) \\ 2 Departamento de Investigación y Posgrado, Facultad de Ciencias Químicas, Universidad Autónoma de \\ Chihuahua, Circuito Universitario s/n Campus Universitario 2, Chihuahua, Chih 31125, Mexico; \\ mruizg@uach.mx \\ * Correspondence: amchavez@uach.mx; Tel.: +52-614-239-8948
}

Academic Editors: Eulogio J. Llorent-Martínez and Ruperto Bermejo-Román

Received: 16 October 2020; Accepted: 19 November 2020; Published: 24 November 2020

\begin{abstract}
Betalains are powerful antioxidants contained in beets. These are divided into betacyanins (red-violet) and betaxanthins (yellow-orange), and they can be used as natural colorants in the food industry. The effects of freeze-drying pure beet juice (B) and the encapsulation of beet juice with a dextrose equivalent (DE) 10 maltodextrin (M) and agave inulin (I) as carrier agents were evaluated. The powders showed significant differences $(p<0.05)$ in all the variables analyzed: water absorption index (WAI), water solubility index (WSI), glass transition temperature $\left(\mathrm{T}_{\mathrm{g}}\right)$, total betalains (TB), betacyanins (BC), betaxanthins (BX), total polyphenols (TP), antioxidant activity (AA, via 2,2'-azino-bis(3-ethylbenzothiazoline-6-sulfonic acid)) (ABTS), and 2,2-diphenyl-1-picrylhydrazyl (DPPH)) and total protein concentration (TPC). The highest values of antioxidant activity were found in the non-encapsulated beet powder, followed by the powder encapsulated with maltodextrin and, to a lesser extent, the powder encapsulated with inulin. The glass transition temperature was $61.63{ }^{\circ} \mathrm{C}$ for $\mathrm{M}$ and $27.59^{\circ} \mathrm{C}$ for I. However, for B it was less than $18.34{ }^{\circ} \mathrm{C}$, which makes handling difficult. Encapsulation of beet extract with maltodextrin and inulin by lyophilization turned out to be an efficient method to increase solubility and diminish hygroscopicity.
\end{abstract}

Keywords: betalains; encapsulation; lyophilization; antioxidant activity; polyphenols

\section{Introduction}

The beet (Beta vulgaris rubra) is a member of the Chenopodiaceae family [1]. This family includes important food crops such as chard (Beta vulgaris cicla) and spinach (Spinacia oleracea) [2]. It is a nutritious food that is generally consumed in juices, salads, pickled or cooked [3]. Beet extract has been used as a pigment in the cosmetic, pharmaceutical, and food industries [4-13]. Also, it is a potential source of nutrients and can be used as an ingredient in making healthy foods. [14]. Beets contain betalains, a unique class of antioxidants $[15,16]$. These are classified into two groups: betacyanins, which exhibit a red-violet coloration, and betaxanthins, which impart a yellow-orange pigmentation [4,17-20]. Beet extract is a color approved under code 73.40 by the FDA [21] and by the EU designated with the number E162 [1,22].

Betalains have low stability to various factors, such as high temperatures [23], alkaline $\mathrm{pH}$ [24], enzymatic activity [25], presence or absence of light [26], oxygen and/or metals [18,27]. Due to the instability of betahalamic compounds, their use has been restricted in food [19,28-33]. Encapsulation has been used to protect bioactive compounds contained in foods such as essential oils, vitamins, 
antioxidants, bactericides, colorants, flavorings, among others [34-37]. This is a process by which phytochemicals are coated with a thin wall of a protective material called a carrier or encapsulating agent [38-43]. Encapsulation of betalains in different edible matrices has been shown to increase their stability and maintain its antioxidant activity [3,28,44-50]. There are a great variety of techniques to carry out encapsulation, some authors have classified them as chemical and physical [51]. At the time of encapsulation, it should be taken into account that there are complications related to caking, particle agglomeration and stickiness, as a result of the low glass transition temperature $\left(T_{g}\right)$ [52] . Due to these, it is necessary to use encapsulating agents that increase said parameter (high molecular weight and low viscosity) [43]. Among the physical or mechanical techniques appear: fluidized bed drying, extrusion, lyophilization and spray drying [53,54]. However, little has been studied on the properties of the bioactive compounds found in beet extract encapsulated by lyophilization. Therefore, the physicochemical characteristics of these powders could be evaluated due to their use as a pigments with antioxidant activity; since they represent a good alternative for the development of new functional food products. The objective of this study was to evaluate the effect of encapsulation by lyophilization on the physicochemical characteristics (water absorption index, water solubility index and glass transition temperature) and bioactive compounds (total betalains, betacyanins, betaxanthins, total polyphenols, antioxidant activity and total protein concentration) of betabel extract.

\section{Results and Discussion}

The powders (Figure 1) presented significant differences $(p<0.05)$ in all variables analyzed: water absorption index (WAI), water solubility index (WSI), glass transition temperature $\left(\mathrm{T}_{\mathrm{g}}\right)$, total betalains (TB), betacyanins (BC), betaxanthins (BX), total polyphenols (TP), antioxidant activity (AA) (via 2,2'-azino-bis(3-ethylbenzothiazoline-6-sulfonic acid)) (ABTS), and 2,2-diphenyl-1-picrylhydrazyl $(\mathrm{DPPH})$ ) and total protein concentration (TPC). Table 1 shows the physicochemical characterization of beet juice powders.

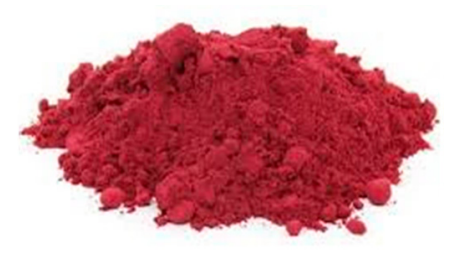

(a)

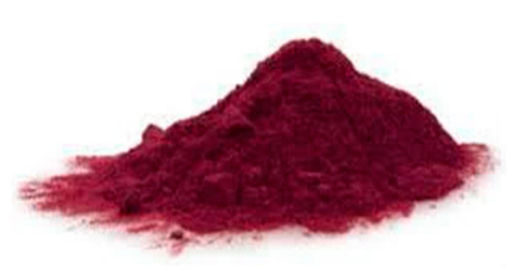

(b)

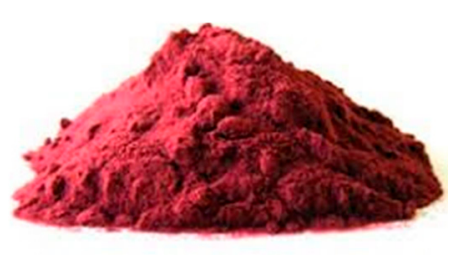

(c)

Figure 1. Freeze-dried beet powders: (a) pure beet powder; (b) maltodextrin encapsulated beet powder; (c) beet powder encapsulated with inulin.

Table 1. Physicochemical characterization of lyophilized extracts of beet (Beta vulgaris sp.) (Mean \pm Standard Error).

\begin{tabular}{|c|c|c|c|c|c|}
\hline Powder & WAI & WSI & $\underset{\left({ }^{\circ} \mathbf{C}\right)}{\mathbf{T}_{\mathbf{g}}}$ & $\begin{array}{c}\text { ABTS } \\
(\mathrm{mM} \mathrm{TE} / 100 \mathrm{~g})\end{array}$ & $\begin{array}{c}\text { DPPH } \\
(\mathrm{mM} \mathrm{TE} / 100 \mathrm{~g})\end{array}$ \\
\hline B & $44.007 \pm 1.000^{a}$ & $9.051 \pm 0.016^{b}$ & $18.340 \pm 0.953^{c}$ & $0.907 \pm 0.001^{a}$ & $0.447 \pm 0.001^{a}$ \\
\hline $\mathbf{M}$ & $27.095 \pm 6.096^{b}$ & $9.374 \pm 0.014^{\mathrm{a}}$ & $61.633 \pm 1.261^{\mathrm{a}}$ & $0.741 \pm 0.001^{b}$ & $0.295 \pm 0.001^{b}$ \\
\hline $\mathbf{I}$ & $30.684 \pm 3.427^{b}$ & $8.955 \pm 0.023^{c}$ & $27.593 \pm 0.382^{b}$ & $0.647 \pm 0.001^{c}$ & $0.208 \pm 0.001^{\mathrm{c}}$ \\
\hline Powder & $\begin{array}{c}\text { TP } \\
(\mathrm{mg} \mathrm{GAE} / \mathrm{g})\end{array}$ & $\begin{array}{c}\text { TB } \\
(\mathrm{mg} / \mathbf{1 0 0} \mathrm{g})\end{array}$ & $\begin{array}{c}\text { BC } \\
(\mathrm{mg} / \mathbf{1 0 0} \mathrm{g})\end{array}$ & $\begin{array}{c}\text { BX } \\
(\mathbf{m g} / \mathbf{1 0 0} \mathrm{g})\end{array}$ & $\begin{array}{c}\text { TPC } \\
(\mu \mathrm{g} / \mathrm{mL})\end{array}$ \\
\hline B & $12.354 \pm 0.001^{a}$ & $382.351 \pm 0.092^{a}$ & $219.175 \pm 0.092^{a}$ & $163.176 \pm 0.001^{a}$ & $5.974 \pm 0.001^{a}$ \\
\hline $\mathbf{M}$ & $6.093 \pm 0.001^{b}$ & $15.718 \pm 0.016^{b}$ & $10.001 \pm 0.001^{b}$ & $5.717 \pm 0.006^{b}$ & $3.524 \pm 0.001^{c}$ \\
\hline I & $5.975 \pm 0.001^{\mathrm{c}}$ & $10.110 \pm 0.016^{\mathrm{c}}$ & $6.279 \pm 0.001^{c}$ & $3.831 \pm 0.006^{\mathrm{c}}$ & $3.655 \pm 0.001^{b}$ \\
\hline
\end{tabular}

$\mathrm{B}=$ Unencapsulated beet extract. $\mathrm{M}=$ Beet extract encapsulated with Maltodextrin. $\mathrm{I}=$ Beet extract encapsulated with Inulin. WAI = Water Absorption Index, WSI = Water Solubility Index, $\mathrm{T}_{\mathrm{g}}=$ Glass Transition Temperature, Antioxidant Activity by 2,2'-azino-bis(3-ethylbenzothiazoline-6-sulfonic acid)) (ABTS), and 2,2-diphenyl-1-picrylhydrazyl $(\mathrm{DPPH}), \mathrm{TP}=$ Total Polyphenols, $\mathrm{TB}=$ Total Betalains, $\mathrm{BC}=$ Betacyanins, $\mathrm{BX}=$ Betaxanthins and TPC $=$ Total protein concentration. ${ }^{\mathrm{a}, \mathrm{b}, \mathrm{c}}$ Different literals between rows indicate significant statistical difference $(p<0.05)$. 


\subsection{Yield of Encapsulation}

The yield of the powders was found in a range from 35,772 to $65,329 \mathrm{~g} / 100 \mathrm{~g}$, with the highest percentage presented in the powder encapsulated with dextrose equivalent (DE) 10 maltodextrin (M) $(65,329 \mathrm{~g} / 100 \mathrm{~g})$, while the powder encapsulated with agave inulin (I) indicated $61,678 \mathrm{~g} / 100 \mathrm{~g}$. The non-encapsulated powder (B) had a yield of $35,772 \mathrm{~g} / 100 \mathrm{~g}$, which was the lowest yield. The yield values found in this study are greater than the values found by Castro-Muñoz Saenz et al., 2009 [55] in the encapsulation of clarified juice from purple cactus pear (Opuntia stricta), using a combination of maltodextrin and gelatin (range yields between 7.76-14.85 g/100 g). Meanwhile, Obón et al. (2009) [56] reported yield values of $58 \mathrm{~g} / 100 \mathrm{~g}$ using glucose syrup as an encapsulant agent. Likewise, Saenz et al., 2009 [57] mentioned yield values between 23 and $81 \mathrm{~g} / 100 \mathrm{~g}$ using maltodextrin or inulin. All these authors used spray drying for the encapsulation. The high yield values found in this study may be due to the affinity of the wall material, the encapsulated compounds [47,48], and the higher recovery and lower degradation of betalains during freeze-drying compare to spray drying [48,49].

\subsection{Water Absorption Index (WAI)}

In the WAI, percentages of $44.01 \pm 1.000,27.09 \pm 6.096$ and $30.68 \pm 3.427$ were obtained for B, $\mathrm{M}$ and I, respectively. No significant differences were found for I and M values. Higher WAI observed on B may be due to the fact that the hydrophilic functional groups of polyphenols, betalains, betacyanins and betaxanthins are free and can form hydrogen bonds with water molecules. Betacyanins pigments quickly absorb humidity from the environment due its hydrophilic groups and the encapsulation with maltodextrin protects the pigment by allowing the drying process and also helps to reduce hygroscopicity by increasing their stability [58]. Moreover, it would have been expected that $\mathrm{M}$ would show higher WAI values because maltodextrin is more soluble in water than inulin [59]. However, the values could be due to the fact that maltodextrin occupied its binding sites (hydrophilic functional groups) with polyphenols, betalains, betacyanins and betaxanthins, leaving fewer binding sites available to bind with water. The WAI results found in this work are higher than those reported by other authors [60] who indicated $6.04 \%$ of WAI in prickly pear powder encapsulated with soluble barley fiber. Likewise, lower results than those of this research have been reported for the WAI in barley flour (6.42 and 7.26\%), barley-tomato flour (6.10 to 7.03\%) and barley-grape flour $(7.85 \%$ to $15.79 \%)$. However, the powders in this study were obtained by extrusion [61]. Also, WAI values of $1.92,4.48$ and $2.31 \%$ were reported in wheat, potato and quinoa flours, respectively [62]. The WAI is related to the humidity of the product under certain conditions of relative humidity and temperature; and it can be used as an indication of the degree of modification of starches by thermomechanical treatments [62].

\subsection{Water Solubility Index (WSI)}

The WSI values were $8.95 \pm 0.023 \%, 9.05 \pm 0.016 \%$ and $9.37 \pm 0.014 \%$ for $\mathrm{B}, \mathrm{I}$ and $\mathrm{M}$, respectively. This indicates that when exposed to water, the powder encapsulated with M presents greater solubility $(p<0.05)$ compared to B and I. Water holding capacity is usually defined as the amount of water retained or absorbed by a specific compound after acquiring the state of equilibrium. High water holding capacity is directly related with the presence of hydrophilic regions in the chemical structure [63]. This is also associated with dextrinization and used as an indicator of the degradation of the molecular structure of polymers present in starch and dietary fiber [64]. I presented the lowest value of WSI, this could be due to the decrease of the hydrophilic groups available to bind water, that could be occupying linking polyphenols, betalains, betacyanins and betaxanthins (Figure 2). Besides, $\mathrm{M}$ presented the highest values of WSI, this could be due to the fact that maltodextrin has a high capacity to absorb water of $72-83 \%$ [55] compare to inulin 15-49\% [65]. The results found in this work are higher than those reported [66] in prickly pear powder encapsulated with soluble barley fiber, made by spray drying, where values of 0.24 and $0.76 \%$ were reported for the WSI. Likewise, the WSI was evaluated in wheat, 
potato and quinoa flours, and reported percentages of 2.09, 7.45 and 5.10 [62], respectively. On the other hand, the WSI values obtained in this study are within the range reported in barley flour (6.27 to $9.67 \%$ ), barley-tomato flour (7.08 to $12.99 \%$ ) and barley-grape flour (7.85 to 15.79\%). Nevertheless, the powders in these study were obtained by extrusion [61]. Advantages of using polysaccharides to encapsulate betalains include their solubility, bland flavor, low hygroscopicity and ability to protect bioactive compounds from oxidation.

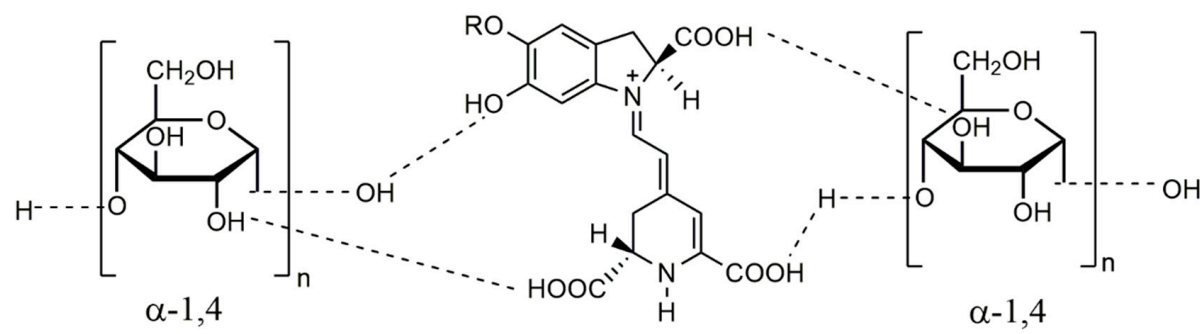

$\begin{array}{lll}\text { Maltodextrin } & \text { Betacyanins } & \text { Maltodextrin }\end{array}$

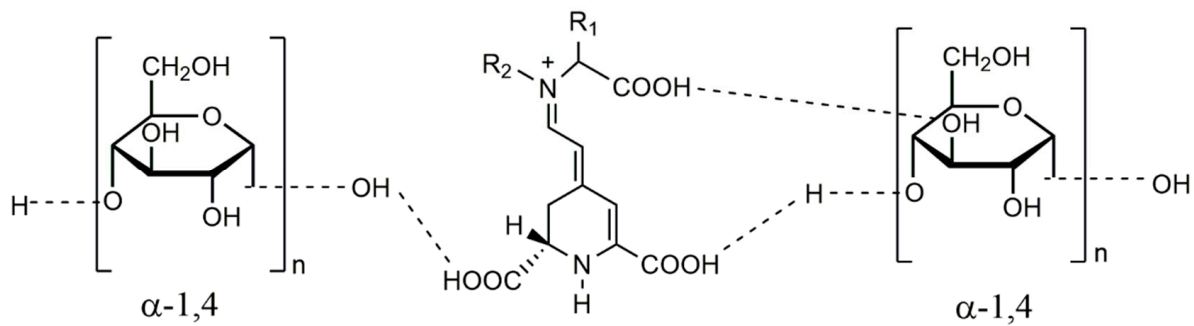

Maltodextrin

Betaxanthins

Maltodextrin

Hydrogen Bonding

Figure 2. Interaction between maltodextrin with betaxanthins and betacyanins.

\subsection{Glass Transition Temperature $\left(T_{g}\right)$}

The $\mathrm{T}_{\mathrm{g}}$ values presented had significant differences $(p<0.05)$ between the powders, with values of $18.34{ }^{\circ} \mathrm{C}$ for $\mathrm{B}, 27.59{ }^{\circ} \mathrm{C}$ for I, and $61.63{ }^{\circ} \mathrm{C}$ for $\mathrm{M}$. This property is important since it is related to the stability of the product [66]. Low $\mathrm{T}_{\mathrm{g}}$ values indicate a high hygroscopicity of the powder [67], with $\mathrm{B}$ being the powder with the greatest capacity to absorb moisture. This result is due to the fact that the hydrophilic groups of betalains, betacyanins, and betaxanthins are available to form hydrogen bonding with water. While in encapsulated products, these binding sites are used to form hydrogen bonds with the hydrophilic functional groups of maltodextrin and inulin (Figure 2). Betacyanin pigments quickly absorb humidity from the environment due to their hydrophilic groups, and the encapsulation with maltodextrin protects the pigment by allowing the drying process and when at the same time, helps to reduce hygroscopicity and increase their stability [58]. In general, the $\mathrm{T}_{\mathrm{g}}$ values obtained in this investigation were lower than those reported in other studies, in which the $\mathrm{T}_{\mathrm{g}}$ was in the range of 32.27 to $387.10^{\circ} \mathrm{C}[3,28,47,66,67]$. The addition of encapsulating agents such as maltodextrins, inulins, and gums have been shown to lead to a considerable increase in $\mathrm{T}_{\mathrm{g}}$, largely confirming the stability of betalains $[3,28,47,66,67]$. Also, it has been reported that beet juice encapsulated with Arabic gum has $\mathrm{T}_{\mathrm{g}}$ values between 98.96 and $105.86^{\circ} \mathrm{C}$ when using the spray drying method [3]. Likewise, the encapsulation of beet pigments with maltodextrin and acacia has a $\mathrm{T}_{\mathrm{g}}$ of $90{ }^{\circ} \mathrm{C}$ [47]. Meanwhile, red prickly pear betalains encapsulated with soluble barley fiber by spray drying obtained a $\mathrm{T}_{\mathrm{g}}$ in the 
range of 32.27 to $38.11^{\circ} \mathrm{C}$ [66]. In amaranth, betalains encapsulated by means of spray drying with maltodextrin, a $\mathrm{T}_{\mathrm{g}}$ of $54.7^{\circ} \mathrm{C}$ was reported [67].

\subsection{Total Betalains Content (TB)}

The average betalain content of beets is approximately $130 \mathrm{mg} / 100 \mathrm{~g}$ [68,69]; however, new varieties of beets produce around $450-500 \mathrm{mg} / 100 \mathrm{~g}$ of betahalamic pigments [70]. Table 1 shows the TB content of this study. The concentration of TB in B was $382.35 \pm 0.092$, being $219.17 \pm 0.092 \mathrm{mg} / 100 \mathrm{~g}$ of BC and $163.17 \pm 0.001 \mathrm{mg} / 100 \mathrm{~g}$ of $\mathrm{BX}$. The content of encapsulated TB $(\mathrm{M}=15.71 \pm 0.016 \mathrm{mg} / 100 \mathrm{~g}$; $\mathrm{I}=10.11 \pm 0.016 \mathrm{mg} / 100 \mathrm{~g}$ ) in this investigation did not coincide with the results obtained by other authors who reported a TB concentration lower than $121.6 \mathrm{mg} / 100 \mathrm{~g}$ [49] in unencapsulated beet powder. Other studies have reported $77.70 \mathrm{mg} / 100 \mathrm{~g}, 28.82 \mathrm{mg} / 100 \mathrm{~g}$ and $11.97 \mathrm{mg} / 100 \mathrm{~g}$ of TB in beet powders $[45,47,71]$. However, these authors used maltodextrin and Arabic gum and mixtures of both agents to encapsulate the powder by spray drying. On the other hand, the TB content in prickly pear powders encapsulated with maltodextrin and gelatin in different proportions ranged from 11.33 to $35.93 \mathrm{mg} / 100 \mathrm{~g}$ [55]. Furthermore, the TB content of 49.1 to $52.1 \mathrm{mg} / 100 \mathrm{~g}$ was reported in powders of prickly pear encapsulated with K-4484 and Capsul ${ }^{\circledR}$ by spray drying [72]. Also, values between 42.0 to $88.0 \mathrm{mg} / 100 \mathrm{~g}$ of TB have been reported in powders of prickly pear encapsulated with maltodextrin and inulin by spray drying [57]. The higher stability and, as a consequence, the presence of betacyanins over betaxanthins may be due to the fact that some of them have a glycosylated structure, which has a high oxidation-reduction potential $[30,31,71]$. Variation in anthocyanin content is related to the type of encapsulated agent and its behavior during freeze-drying [73]. The encapsulation efficiency depends on the capacity of the wall materials to hold in the core of the microparticles the component to encapsulate; in this case, it is attributed to the capability of the biopolymeric wall materials (maltodextrin and inulin) to interact with betalains. Maltodextrin and inulin alone can interact with betacyanins and betaxanthins through hydrogen bonding (Figures 2 and 3).
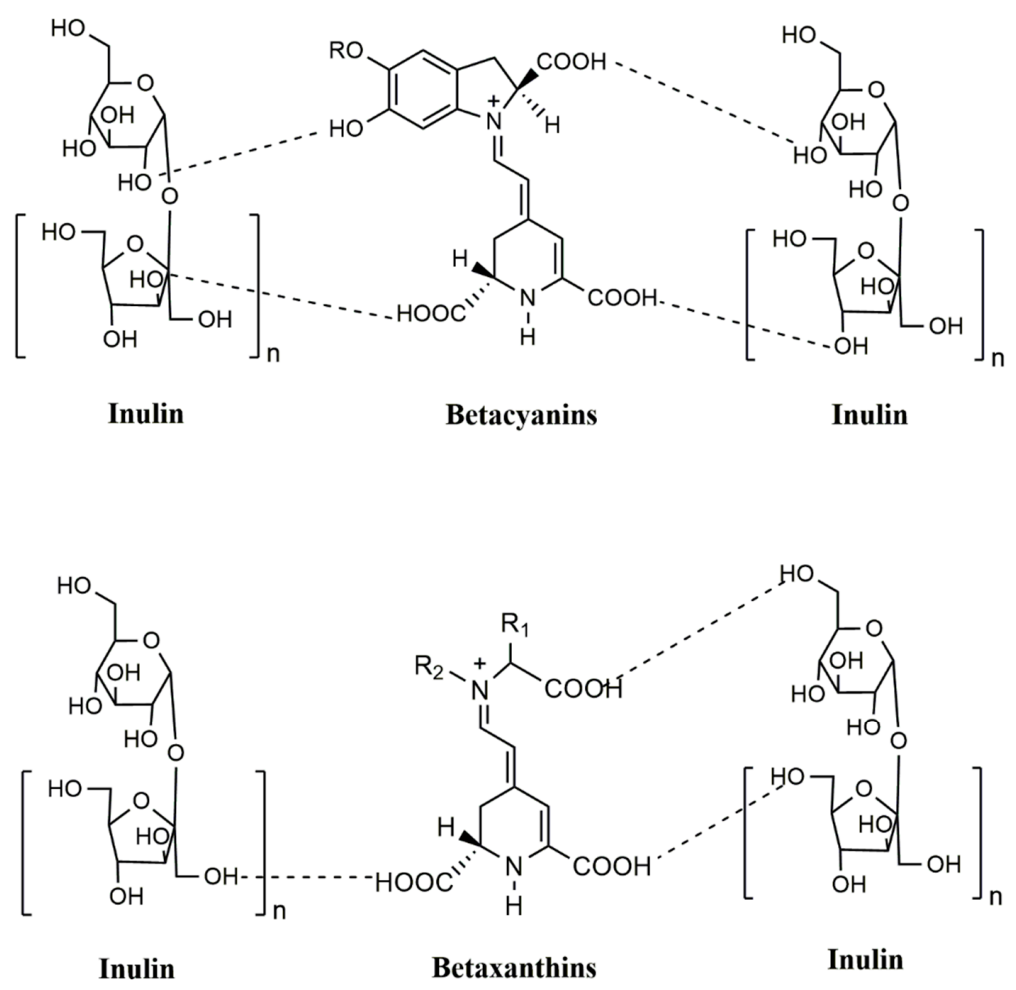

Hydrogen Bonding

Figure 3. Interaction between inulin with betaxanthins and betacyanins. 


\subsection{Total Polyphenols Content (TP)}

The content of TP (Table 1) was found in a range of 5.97 to 12.35 milligrams gallic acid equivalent per gram (mg GAE/g) in this study. For B it was $12.35 \pm 0.001 \mathrm{mg} \mathrm{GAE} / \mathrm{g}$, being the powder with the highest content of total polyphenols, followed by $\mathrm{M}$ with a value of $6.09 \pm 0.001 \mathrm{mg} \mathrm{GAE} / \mathrm{g}$ and then I where $5.97 \pm 0.001 \mathrm{mg} \mathrm{GAE} / \mathrm{g}$ was found. These results are higher than those previously reported by other authors, who reported $4.88 \mathrm{mg}$ GAE/g TP in maltodextrin encapsulated beet powder by lyophilization [49]. In prickly pear powder encapsulated with soluble fiber by spray drying, ranges from 14.2 to $16.5 \mathrm{mg} \mathrm{GAE} / \mathrm{g}$ of TP content were reported [66]. Also, values of 1.81 to $2.41 \mathrm{mg}$ GAE/g have been mentioned in terms of TP content in prickly pear powders encapsulated with maltodextrin and inulin by spray drying [57]. On the other hand, TP content between 0.41 and $0.81 \mathrm{mg}$ GAE/g has been reported in yellow pitahaya powder encapsulated with maltodextrin by spray drying [43].

\subsection{Antioxidant Activity $(A A)$}

The AA of the beet powders $(\mathrm{B}, \mathrm{M}$, and $\mathrm{I})$ was maintained in a range of 0.65 to $0.91 \mathrm{mM} \mathrm{TE} / 100 \mathrm{~g}$ using the ABTS methodology and DPPH from $0.21 \pm 0.001$ to $0.45 \pm 0.001 \mathrm{mM} \mathrm{TE} / 100 \mathrm{~g}$, with significant differences $(p<0.05)$ between the powders using both techniques. The highest AA was for the beet powder without carrier agent (B) with an ABTS value of $0.90 \pm 0.001 \mathrm{mM}$ TE/100 $\mathrm{g}$ and $0.44 \pm 0.001 \mathrm{mM}$ TE/100 g using DPPH. The beet extract encapsulated with maltodextrin (M) was ranked second with values of $0.74 \pm 0.001 \mathrm{mM}$ TE/100 $\mathrm{g}$ in the ABTS technique and using DPPH with $0.29 \pm 0.001 \mathrm{mM}$ $\mathrm{TE} / 100 \mathrm{~g}$, while the extract encapsulated with inulin (I) presented the lowest antioxidant activity with a value of $0.64 \pm 0.001 \mathrm{mM}$ TE/100 $\mathrm{g}$ and $0.20 \pm 0.001 \mathrm{mM} \mathrm{TE} / 100 \mathrm{~g}$, with ABTS and DPPH, respectively. The values obtained in this research are higher than those previously reported in yellow pitaya powders encapsulated with maltodextrin by spray drying (0.07 mM TE/100 $\mathrm{g}$ for ABTS and 0.09 mM TE/100 $\mathrm{g}$ using DPPH) [43]. In prickly pear powders encapsulated with maltodextrin and inulin by spray drying, AA values ranged from 0.004 to $0.029 \mathrm{mM}$ TE/100 $\mathrm{g}$ using the DPPH method [55].

\subsection{Total Protein Concentration (TPC)}

Significant differences $(p<0.05)$ were found in the TPC. The values were $5.974 \pm 0.001$ for beet extract without encapsulation (B), $3.524 \pm 0.001$ for the beet extract encapsulated with maltodextrin $(\mathrm{M})$, and $3.655 \pm 0.001$ for the beet extract encapsulated with inulin (I).

\subsection{Correlation between Variables}

Table 2 shows the correlation coefficient ( $\mathrm{r}$ ) and its level of significance between the response variables of the lyophilized beet extracts ( $\mathrm{B}, \mathrm{M}$, and I). All powders showed similar behaviors in the variables analyzed: total betalains (TB), betacyanins (BC), betaxanthins (BX), total polyphenols (TP), antioxidant activity (AA) by both methods (ABTS and DPPH), and total protein concentration (TPC).

Among the most important correlations, a positive correlation was found between AA and TP $(\mathrm{r}=0.9398$ in ABTS, and $\mathrm{r}=0.9388$ in DPPH $p<0.0002)$. This may be because polyphenols are powerful antioxidants [74]. A positive correlation was found between AA and TB ( $\mathrm{r}=0.9293$ in ABTS and $r=0.9283$ in DPPH, $p<0.0003$ ). This could be due to the presence of bethalamic acid since it acts as an antioxidant agent. Similar results have been reported in red prickly pear extract [55]. A positive correlation was found between AA and TPC ( $\mathrm{r}=0.9500$, in ABTS and $\mathrm{r}=0.9491$ in DPPH, $p<0.0001)$. This could be attributed to the fact that sugars and proteins generate products with high antioxidant activity [75], which can be observed despite the presence of betalains [55]. A positive correlation between TB and TP was also found $(r=0.9996, p<0.0001)$. This could be because betalains are the main polyphenols present in beets [49]. A negative correlation was found between WAI and $\mathrm{T}_{\mathrm{g}}(\mathrm{r}=0.7410$, $p<0.0224$ ), which may be due to the powders beginning to hydrate at relatively low temperatures [45]. 
Table 2. Correlation coefficient and the level of significance ( $p$-value) between the response variables of encapsulated freeze-dried beet extracts (Beta vulgaris sp.).

\begin{tabular}{cccccccccc}
\hline & WSI & $\mathbf{T}_{\mathbf{g}}$ & ABTS & DPPH & TP & TB & BC & BX & TPC \\
\hline WAI & -0.4519 & -0.7410 & 0.8968 & 0.8963 & 0.8933 & 0.8882 & 0.8878 & 0.8887 & 0.8982 \\
$p$-value & 0.2220 & 0.0224 & 0.0011 & 0.0011 & 0.0012 & 0.0014 & 0.0014 & 0.0014 & 0.0010 \\
WSI & & 0.9068 & -0.6166 & -0.6188 & -0.3118 & -0.2838 & -0.2817 & -0.2865 & -0.3412 \\
$p$-value & & 0.0007 & 0.0770 & 0.0756 & 0.4141 & 0.4593 & 0.4627 & 0.4549 & 0.3689 \\
T $_{\mathbf{g}}$ & & & -0.8872 & -0.8885 & -0.6768 & -0.6549 & -0.6533 & -0.6571 & -0.6995 \\
$p$-value & & & 0.0014 & 0.0014 & 0.0453 & 0.0556 & 0.0564 & 0.0545 & 0.0360 \\
ABTS & & & 1.0000 & 0.9398 & 0.9293 & 0.9285 & 0.9304 & 0.9500 \\
$p$-value & & & $<0.0001$ & 0.0002 & 0.0003 & 0.0003 & 0.0003 & $<0.0001$ \\
DPPH & & & & 0.9388 & 0.9283 & 0.9275 & 0.9293 & 0.9491 \\
$p$-value & & & & 0.0002 & 0.0003 & 0.0003 & 0.0003 & $<0.0001$ \\
TP & & & & & 0.9996 & 0.9995 & 0.9997 & 0.9995 \\
$p$-value & & & & & $<0.0001$ & $<0.0001$ & $<0.0001$ & $<0.0001$ \\
TB & & & & & & 1.0000 & 1.0000 & 0.9982 \\
$p$-value & & & & & & $<0.0001$ & $<0.0001$ & $<0.0001$ \\
BC & & & & & & & & $<.0000$ & 0.9980 \\
$p$-value & & & & & & & & $<0.0001$ & $<0.0001$ \\
BX & & & & & & & & 0.9983 \\
$p$-value & & & & & & & & & \\
\hline
\end{tabular}

WAI = Water absorption index, WSI $=$ Water solubility index, $\mathrm{T}_{\mathrm{g}}=$ Glass transition temperature, $\mathrm{ABTS}$ and DPPH $=$ Antioxidant activity, $\mathrm{TP}=$ Total polyphenols, $\mathrm{TB}=$ Total betalains, $\mathrm{BC}=$ Betacyanins, $\mathrm{BX}=$ Betaxanthins and $\mathrm{TPC}=$ Total protein concentration. $p$-value $=$ Level of significance of the correlation .

\section{Materials and Methods}

\subsection{Materials}

The beet was acquired in a local market in Chihuahua, Mexico, during the period from March to July 2018. In addition, maltodextrin (DE 10) and agave inulin, both from Sigma-Aldrich ${ }^{\circledR}$, St. Louis, MO, USA, were used as carrier agents in the encapsulation of beet juice. The powders were characterized in terms of water absorption and solubility index, glass transition temperature, total betalains content, betacyanins, betaxanthins, total polyphenols content, antioxidant activity by the ABTS and DPPH methods, and total protein concentrations.

\subsection{Reagents}

The 2,2'-azino-bis(3-ethylbenzothiazoline-6-sulfonic acid) (ABTS), 2,2-diphenyl-1-picrylhydrazyl (DPPH), Trolox, ammonium salt, potassium persulfate, Folin-Ciocalteu, sodium carbonate, gallic acid, trichloroacetic acid, citrate, and phosphate standard reagent were purchased from Sigma-Aldrich (St. Louis, MO, USA). High-performance liquid chromatography (HPLC)-grade methanol and HPLC-grade water were purchased from J. T. Baker (Mexico City, Mexico). Deionized water was obtained using a deionizer (Barnstead, Thermo Scientific, Waltham, MA, USA). All other reagents used were analytical grade.

\subsection{Preparation of Beet Juice Powders}

\subsubsection{Obtaining Beet Juice, Encapsulation, and Lyophilization}

The beet juice was extracted with a domestic extractor (Cold Press 900W, Breville, Syndney, Australia). The encapsulating agents (Maltodextrin-M and Inulin-I) were added following the technique used by Antigo et al., 2017 [49] in an amount of $30 \mathrm{~g}$ of dry matter per $100 \mathrm{~mL}$ to the red beet juice at room temperature. Then mixtures were homogenized for $10 \mathrm{~min}$ (Vortex-Ultra-Turrax IKA T18 basic) with a dispersion tool (S18N-19G, IKA Works Inc., Wilmington, NC, USA). For encapsulation by freeze-drying, the samples were frozen for $48 \mathrm{~h}$ at $-20^{\circ} \mathrm{C}$. Then, these were dried by freeze-drying for four days (at $-85^{\circ} \mathrm{C}$ and 0.035 mbar pressure) to ensure complete drying of the product (Freeze-dryer 
Labconco Niro Mobile Minor DK-2860, GEA Company, Kansas City, MO, USA). Three powders were obtained: pure beet (B), beet extract encapsulated with maltodextrin (M), and beet extract encapsulated with inulin (I). Powders were stored at $9 \pm 3{ }^{\circ} \mathrm{C}$ for later analysis.

\subsubsection{Yield of Encapsulation}

The lyophilization yield was calculated using the technique described by Castro-Muñoz et al., 2015 [55], by determining the recovered powder; according to the following equation

$$
\mathrm{YE}(\%)=\left[\left(\mathrm{W}_{2} / \mathrm{W}_{1}\right) \times(100)\right]
$$

where $\mathrm{YE}=$ the yield $\left(\mathrm{g} 100 \mathrm{~g}^{-1}\right), \mathrm{W}_{2}=$ weight $(\mathrm{g})$ of the collected product, and $\mathrm{W}_{1}=$ weight $(\mathrm{g})$ of mass in the feed.

\subsubsection{Aqueous Extract}

The extracts used to determine the content of total polyphenols and antioxidant activity were obtained according to Pitalua et al., 2010 [45] with some modifications. Briefly, $0.5 \mathrm{~g}$ of powder was dispersed in $10 \mathrm{~mL}$ of methanol and deionized water $(1: 1 \mathrm{v} / \mathrm{v})$. The dispersions were homogenized for $15 \mathrm{~s}$ (Vortex-Ultra-Turrax IKA T18 basic) with a dispersion tool (S18N-19G, IKA Works Inc., Wilmington, NC, USA). The mixture was then centrifuged at $3000 \times g$ for $10 \mathrm{~min}$ (Centrifuge-Centra Avanti ${ }^{\circledR} \mathrm{J}-26$ XPI. Beckman Coluter $^{\circledR}$, Indianapolis, IN, USA). Supernatants were filtered using a $0.42 \mu \mathrm{m}$ pore polyethylene filter (Millipore Corp., Bedford, MA, USA) and stored frozen $\left(-20 \pm 3^{\circ} \mathrm{C}\right)$ until analysis.

\subsection{Characterization of Beet Juice Powders}

\subsubsection{Water Absorption and Solubility Index}

The WAI and WSI were determined according to a method previously reported by Anderson et al., 1970 [76] with some modifications. A sample of $0.5 \mathrm{~g}$ (Analytical Balance-PA214C, OHAUS Pioneer, Parsippany, NJ, USA) was weighed and added to $6 \mathrm{~mL}$ of deionized water at $30{ }^{\circ} \mathrm{C}$ and incubated (Recirculation Water Bath-WBC22, WiseCircu, Wertheim, Germany) for $30 \mathrm{~min}$. Subsequently, it was centrifuged at $3000 \times g$ for 10 min (Centrifuge-Centra Avanti J-26 XPI, Beckman Coulter, Indianapolis, IN, USA). The supernatant was decanted into a capsule at a constant weight; the new weight was recorded (capsule + supernatant). Then it was dried at $85{ }^{\circ} \mathrm{C}$ for $24 \mathrm{~h}$ and subsequently weighed again (Analytical Balance-PA214C, OHAUS Pioneer, Pine Brook, NJ, USA). The WAI was calculated as the weight of the sediment obtained after removal of the supernatant per unit weight of the original solids on a dry basis. And WSI was the percentage of dry matter recovered after evaporation of the supernatant obtained from WAI. Each determination was carried out in triplicate, and an average value was obtained for each sample.

\subsubsection{Glass Transition Temperature}

The $\mathrm{T}_{\mathrm{g}}$ was determined following the method described by Ahmed et al., 2010 [77] by differential scanning calorimetry (DSC) in Thermal Analysis Instrument equipment (DSC Q-2000, Crawley, UK). A sample of $0.6 \mathrm{mg}$ was placed in each $40 \mu \mathrm{L}$ aluminum cell and sealed. Subsequently, they were subjected to different heating and cooling cycles, all at a heating ramp of $15^{\circ} \mathrm{C} / \mathrm{min}$. The first cycle was from room temperature to $0^{\circ} \mathrm{C}$, the second cycle from $0^{\circ} \mathrm{C}$ to $120^{\circ} \mathrm{C}$, the third cycle from $120^{\circ} \mathrm{C}$ to $0{ }^{\circ} \mathrm{C}$, and the fourth cycle from $0{ }^{\circ} \mathrm{C}$ to $120^{\circ} \mathrm{C}$. An empty cell was used as a reference for all measurements. As a result, thermograms were obtained in which a graph of heat flow (Y-axis) versus temperature (X-axis) was observed. These were analyzed with the Universal Analysis software to obtain the $\mathrm{T}_{\mathrm{g}}$ generated in the fourth heating cycle. Each determination was made in duplicate, and an average value was obtained for each sample. 


\subsubsection{Extraction of Betalains}

The betalains extraction was carried out according to Güneşer, 2016 [12]. Aliquots of $4 \mathrm{~mL}$ of the aqueous extract were placed in Corning tubes and mixed with $4 \mathrm{~mL}$ of the trichloroacetic acid (TCA) solution at a $4 \%$ concentration. Then it was homogenized using a vortex (Ultra-Turrax IKA T18 basic) for 3 min and centrifuged at $4032 \times g$ (Avanti ${ }^{\circledR}$ J-26 XPI. Beckman Coluter ${ }^{\circledR}$, Indianapolis, IN, USA) for $10 \mathrm{~min}$ at $25^{\circ} \mathrm{C}$. The supernatant was filtered through a $0.45 \mu \mathrm{m}$ pore polyethylene filter (Millipore Corp., Bedford, MA, USA). Samples were kept at $-20^{\circ} \mathrm{C}$ until analysis.

\subsubsection{Total Betalains Content}

The photometric quantification of total betalains was determined following the method described by Ruíz-Gutiérrez et al., 2014 [66]. The aqueous extracts of B were diluted with McIlvaine buffer ( $\mathrm{pH}$ 6.5, citrate-phosphate in a 1 to 10 ratio. However, for $\mathrm{M}$ and $\mathrm{I}$, to obtain values at their respective absorption maxima, this dilution was not necessary. TB was calculated as follows

$$
\mathrm{B}[\mathrm{mg} / \mathrm{g}]=[(\mathrm{A} \times \mathrm{DF} \times \mathrm{MW} \times \mathrm{V}) /(\mathrm{E} \times \mathrm{L})]
$$

where: $\mathrm{A}=$ value at maximum absorption (534 for BC and 480 for $\mathrm{BX}$ ) at $600 \mathrm{~nm}, \mathrm{DF}=$ dilution factor, $\mathrm{MW}=$ molecular weight $(550 \mathrm{~g} / \mathrm{mol}$ for BC and $308 \mathrm{~g} / \mathrm{mol}$ for BX), $\mathrm{V}=$ volume of the solution $(1000 \mathrm{~mL})$, $\mathrm{E}=$ molar extinction coefficient $(60,000 \mathrm{~L} / \mathrm{mol} \mathrm{cm}$ for BC and $48,000 \mathrm{~L} / \mathrm{mol} \mathrm{cm}$ for BX), and $\mathrm{L}=$ length of the reading cell $(1 \mathrm{~cm})$.

The quantification of BC and BX were calculated separately, and these two results were added to determine the BT content. These measurements were carried out in triplicate, and the results obtained were expressed in $\mathrm{mg} / 100 \mathrm{~g}$ of powder.

\subsubsection{Total Polyphenols Content}

The standard curve for TP was performed according to what was reported by $\mathrm{Xu}$ and Chang, 2007 [78]. For the calibration curve, a stock solution was prepared by dissolving $0.5 \mathrm{~g}$ of gallic acid in $250 \mathrm{~mL}$ of distilled water. The concentrations used were 400, 300, 200, 150, 100, 80, 60, 40, and 20 ppm.

The TP was determined following the Folin-Ciocalteu spectrophotometric method reported by Singleton and Rossi, 1965 [79] with some modifications and using gallic acid (GA) as a standard. A mixture was prepared by combining $50 \mu \mathrm{L}$ of sample extract with $3 \mathrm{~mL}$ of distilled water, $250 \mu \mathrm{L}$ of Folin-Ciocalteu reagent, and $750 \mu \mathrm{L}$ of sodium carbonate solution (7\%). The mixtures were stirred for $10 \mathrm{~s}$ and stood for $8 \mathrm{~min}$ at room temperature. Subsequently, $950 \mu \mathrm{L}$ of distilled water was added. The mixtures stood for $2 \mathrm{~h}$ at room temperature in the dark. The absorbance was measured at $765 \mathrm{~nm}$ in a UV spectrophotometer (UV-1800. Shimadzu, Japan). Measurements were made in triplicate. The absorbance results were linearized in the regression equation $\left(y=0.0929 x-0.0197 ; r^{2}=0.9991\right)$ obtained from the calibration curve and were expressed in $\mathrm{mg}$ gallic acid equivalent (mg GAE/g).

\subsubsection{Antioxidant Activity}

The standard curve for ABTS and DPPH was performed according to what was reported by Thaipong et al., 2006 [80]. A stock solution was prepared by dissolving $31.3 \mathrm{mg}$ of Trolox (6-hydroxy2,5,7,8-tetramethylchroman-2-carboxylic acid) in $10 \mathrm{~mL}$ of methanol $\left(\mathrm{r}^{2}=0.99\right)$. The dilutions used were $1.20,1.00,0.80,0.60,0.40,0.20,0.10,0.08,0.05$, and $0.03 \mathrm{mM}$.

- $\quad$ AA by ABTS methodology

It was carried out as established by Thaipong et al., 2006 [80]. A solution of ABTS (2,2'-azino-bis (3-ethylbenzothiazoline-6-sulfonic acid)) $7.4 \mathrm{mM}$ was prepared, dissolving $38.8 \mathrm{mg}$ of crystallized ammonium salt of ABTS in $10 \mathrm{~mL}$ of distilled water. Then, a potassium persulfate solution 2.6 $\mathrm{mM}$ was prepared by dissolving $6.6 \mathrm{mg}$ in $10 \mathrm{~mL}$ with distilled water. To generate the ABTS radical, these two solutions were mixed and allowed to stand in the dark at room temperature 
for $12 \mathrm{~h}$. For the ABTS working solution, $1 \mathrm{~mL}$ of the ABTS free radical solution was mixed with $60 \mathrm{~mL}$ of methanol to reach an absorbance of $1.1+0.02$. Subsequently, $150 \mu \mathrm{L}$ of a sample (or standard: Trolox) and $2850 \mu \mathrm{L}$ of ABTS working solution were placed in a $3 \mathrm{~mL}$ plastic cell and allowed to stand for $2 \mathrm{~h}$ in the dark at room temperature, then the absorbance was read at $734 \mathrm{~nm}$ in a UV spectrophotometer (UV-1800. Shimadzu, Japan). Measurements were made in triplicate. The antioxidant capacity was reported as equivalent mM Trolox (mM TE/100 g). For this, the absorbance obtained was substituted in the regression equation $(\mathrm{y}=-1.0726 \mathrm{x}+$ $\left.0.9863 ; \mathrm{r}^{2}=0.9967\right)$ obtained from the Trolox calibration curve.

- AA by DPPH methodology

The antioxidant capacity was determined by the DPPH (2,2-diphenyl- 1-picrylhydrazyl) method established by Thaipong et al., 2006 [80] with slight modifications. First, a stock solution of DPPH was prepared by dissolving $0.0240 \mathrm{~g}$ of DPPH in $100 \mathrm{~mL}$ of methanol to obtain a concentration of $0.6 \mathrm{mM}$. The solution was stored in an amber bottle and frozen at $-20{ }^{\circ} \mathrm{C}$ until used. From this solution, the working solution was prepared, for which $10 \mathrm{~mL}$ of the stock solution were taken and mixed with $45 \mathrm{~mL}$ of methanol to obtain a final concentration of $0.1 \mathrm{mM}$ and an absorbance of $1.1+0.02$. Subsequently, $150 \mu \mathrm{L}$ of sample (or standard: Trolox) and $2850 \mu \mathrm{L}$ of the DPPH working solution was placed in a $3 \mathrm{~mL}$ quartz cell. It was allowed to stand for $3 \mathrm{~h}$ in the dark at room temperature, and then the absorbance was read at $515 \mathrm{~nm}$ on a UV spectrophotometer (UV-1800. Shimadzu, Japan). Measurements were made in triplicate. The antioxidant capacity was reported as equivalent $\mathrm{mM}$ Trolox ( $\mathrm{mM} \mathrm{TE} / 100 \mathrm{~g}$ ) using the absorbance obtained and substituting in the regression equation $\left(y=-1.3055 x+1.1077 ; r^{2}=0.9994\right)$ obtained from the Trolox calibration curve.

\subsubsection{Total Protein Concentration}

The calibration curve corresponding to the TPC was performed according to the method described by Bradford 1976 [81]. Seven standards of bovine serum albumin (BSA) were prepared at different concentrations, and the regression equation was obtained. The absorbance results were linearized in the regression equation of the calibration curve, and the peptide concentration of each of the treatments was analyzed. The dilutions used were 1.20, 1.00, 0.80, 0.60, 0.40, 0.20, and $0.10 \mathrm{mM}$.

The TPC was determined according to the method described by Bradford, 1976 [81]. The proteins react with the bright blue dye, and a product that absorbs strongly at $595 \mathrm{~nm}$ is obtained. For the TPC, $0.1 \mathrm{~mL}$ of the sample and $1 \mathrm{~mL}$ of the Bradford reagent were taken and allowed to react in the dark for $45 \mathrm{~min}$. Once this time had elapsed, the absorbance was taken at $595 \mathrm{~nm}$ in a spectrophotometer (UV-1800 Shimadzu). The absorbance results were linearized in the regression equation $(\mathrm{y}=0.1526 \mathrm{x}-$ $0.0597 ; \mathrm{r}^{2}=0.9973$ ) of the calibration curve and the total protein concentration was expressed in $\mu \mathrm{g} / \mathrm{mL}$ of BSA.

\subsubsection{Statistical Analysis}

Powders characterization results (measured only once in time) were analyzed through an analysis of variance (ANOVA) procedure through the following model

$$
Y i j=\mu+T i+\varepsilon i j
$$

where: Yij $=$ response variable measured in the $j$-th repetition of the $i$-th treatment, $\mu=$ general mean common to all observations, $\mathrm{Ti}=$ effect of the $\mathrm{i}$-th treatment, and $\varepsilon \mathrm{ij}=$ random error measured in the $\mathrm{j}$-th repetition of the i-th treatment; which was assumed to be identically and independently distributed in a normal way with mean $\mu$ and variance $\sigma 2$. When the treatments showed differences, a multiple comparison of means was performed using the Tukey's and Duncan's tests. The program used was SAS 9.0 (Institute Inc., Cary, NC, USA, 2006). 


\section{Conclusions}

The highest values for all the variables were found in the unencapsulated beet powder (B); however, as this has a high hygroscopicity, its handling is difficult. The advantages of using maltodextrin and inulin as encapsulating agents are the high solubility, mild taste, and low hygroscopicity of the obtained powders. The powder encapsulated with maltodextrin $(\mathrm{M})$ presented higher values of the bioactivities analyzed, and also, the powder had a higher $\mathrm{T}_{\mathrm{g}}$, which indicates good stability.

Despite the fact that the total betalain values in the encapsulated powders were lower than those reported in other studies, the encapsulation process by lyophilization turned out to be efficient, suggesting that encapsulated beet powders are promising natural pigments that can be used in a variety of products. In addition, due to its antioxidant activity, these beet powders could have beneficial effects on consumer health.

Author Contributions: M.A.F.-M., Conceptualization and original draft preparation; E.S.-E., Methodology and data analyzed, M.G.R.-G., Conceptualization and methodology; R.S.-V., Conceptualization and methodology; A.C.-M., Conceptualization, leader of the project, provided all necessary resources, writing-review and editing. All authors have read and agreed to the published version of the manuscript.

Funding: This research received no external funding.

Acknowledgments: The authors acknowledge that the Universidad Autónoma de Chihuahua supported this investigation. The Science and Technology National Council of Mexico (CONACYT) provided a graduate study scholarship for Martha Azucena Flores Mancha.

Conflicts of Interest: The authors declare no conflict of interest.

\section{References}

1. Kapadia, G.J.; Subba, R.G. Red Beet Biotechnology; Neelwarne, B., Ed.; Springer: New York, NY, USA, 2013; ISBN 9781461434573.

2. Ninfali, P.; Angelino, D. Nutritional and functional potential of Beta vulgaris cicla and rubra. Fitoterapia 2013, 89, 188-199. [CrossRef] [PubMed]

3. Guadarrama-Lezana, A.Y.; Cruz-Olivares, J.; Martínez-Vargas, S.L.; Carrillo-Navas, H.; Román-Guerrero, A.; Pérez-Alonso, C. Determination of the minimum integral entropy, water sorption and glass transition temperature to establishing critical storage conditions of beetroot juice microcapsules by spray drying. Rev. Mex. Ing. Química 2014, 13, 405-416.

4. Kanner, J.; Harel, S.; Granit, R. BetalainsA New Class of Dietary Cationized Antioxidants Betalains s A New Class of Dietary Cationized Antioxidants. J. Agric. Food Chem 2001, 49, 5178-5185. [CrossRef] [PubMed]

5. Lu, X.; Wang, Y.; Zhang, Z. Radioprotective activity of betalains from red beets in mice exposed to gamma irradiation. Eur. J. Pharmacol. 2009, 615, 223-227. [CrossRef]

6. Szaefer, H.; Krajka-Kuźniak, V.; Ignatowicz, E.; Adamska, T.; Baer-Dubowska, W. Evaluation of the effect of beetroot juice on DMBA-induced damage in liver and mammary gland of female sprague-dawley rats. Phyther. Res. 2014, 28, 55-61. [CrossRef]

7. Kapadia, G.J.; Azuine, M.A.; Sridhar, R.; Okuda, Y.; Tsuruta, A.; Ichiishi, E.; Mukainake, T.; Takasaki, M.; Konoshima, T.; Nishino, H.; et al. Chemoprevention of DMBA-induced UV-B promoted, NOR-1-induced TPA promoted skin carcinogenesis, and DEN-induced phenobarbital promoted liver tumors in mice by extract of beetroot. Pharmacol. Res. 2003, 47, 141-148. [CrossRef]

8. Khan, M.I.; Giridhar, P. Enhanced chemical stability, chromatic properties and regeneration of betalains in Rivina humilis L. berry juice. LWT-Food Sci. Technol. 2014, 58, 649-657. [CrossRef]

9. Khan, M.I.; Giridhar, P. Phytochemistry Plant betalains: Chemistry and biochemistry. Phytochemistry 2015, 117, 267-295. [CrossRef] [PubMed]

10. Georgiev, V.G.; Weber, J.; Kneschke, E.M.; Denev, P.N.; Bley, T.; Pavlov, A.I. Antioxidant activity and phenolic content of betalain extracts from intact plants and hairy root cultures of the red beetroot Beta vulgaris cv. Detroit Dark Red. Plant Foods Hum. Nutr. 2010, 65, 105-111. [CrossRef] [PubMed]

11. Basulto, J.; Moñino, M.; Farran, A.; Baladia, E.; Manera, M.; Bonany, J.; Gelabert, V.; Ballesteros, J.M.; Martínez, A.; Alonso, M.; et al. Human Nutrition and Diet. Spanish J. Hum. Nutr. Diet. 2014, 18, 100-115. [CrossRef] 
12. Güneşer, O. Pigment and color stability of beetroot betalains in cow milk during thermal treatment. Food Chem. 2016, 196, 220-227. [CrossRef] [PubMed]

13. Mereddy, R.; Chan, A.; Fanning, K.; Nirmal, N.; Sultanbawa, Y. Betalain rich functional extract with reduced salts and nitrate content from red beetroot (Beta vulgaris L.) using membrane separation technology. Food Chem. 2017, 215, 311-317. [CrossRef] [PubMed]

14. Vulić, J.J.; Ćebović, T.N.; Ćanadanović-Brunet, J.M.; Ćetković, G.S.; Čanadanović, V.M.; Djilas, S.M.; Tumbas Šaponjac, V.T. In vivo and in vitro antioxidant effects of beetroot pomace extracts. J. Funct. Foods 2014, 6, 168-175. [CrossRef]

15. Netzel, M.; Stintzing, F.C.; Quaas, D.; Straß, G.; Carle, R.; Bitsch, R.; Bitsch, I.; Frank, T. Renal excretion of antioxidative constituents from red beet in humans. Food Res. Int. 2005, 38, 1051-1058. [CrossRef]

16. Mikołajczyk-Bator, K.; Pawlak, S. The effect of thermal treatment on antioxidant capacity and pigment contents in separated betalain fractions. Acta Sci. Pol. Technol. Aliment. 2016, 15, 257-265. [CrossRef]

17. PASCH, J.H.; von ELBE, J.H. Betanine Stability in Buffered Solutions Containing Organic Acids, Metal Cations, Antioxidants, or Sequestrants. J. Food Sci. 1979, 44, 72-75. [CrossRef]

18. von Elbe, J.; Schwartz, S. Colorants. Food Chem. 1996, 3, 651-722.

19. Stintzing, F.C.; Trichterborn, J.; Carle, R. Characterisation of anthocyanin-betalain mixtures for food colouring by chromatic and HPLC-DAD-MS analyses. Food Chem. 2006, 94, 296-309. [CrossRef]

20. Kujawska, M.; Ignatowicz, E.; Murias, M.; Miko, K.; Jodynis-liebert, J. Protective Effect of Red Beetroot against Carbon Tetrachloride- and N-Nitrosodiethylamine-Induced Oxidative Stress in Rats. J. Agric. Food Chem. 2009, 2570-2575. [CrossRef]

21. Rodriguez-Amaya, D.B. Natural food pigments and colorants. Curr. Opin. Food Sci. 2016, 7, 20-26. [CrossRef]

22. Carocho, M.; Morales, P.; Ferreira, I.C.F.R. Natural food additives: Quo vadis? Trends Food Sci. Technol. 2015, 45, 284-295. [CrossRef]

23. Huang, A.; von Elbe, J. Kinetics of the degradation and regeneration of betanine. J. Food Sci. 1985, 50, 1115-1120. [CrossRef]

24. Penfield, M.; Campbell, A. Experimental Food Science. Fruits and Vegetables; Academic Press: San Diego, CA, USA, 1990; pp. 294-330.

25. Slimen, I.B.; Najar, T.; Abderrabba, M. Chemical and antioxidant properties of betalains. J. Agric. Food Chem. 2017, 65, 675-689. [CrossRef] [PubMed]

26. Von Elbe, J.H.; Young Maing, I.; Amundson, C.H. Color stability of betanin. J. Food Sci. 1974, 39, $334-337$. [CrossRef]

27. Wong, Y.M.; Siow, L.F. Effects of heat, $\mathrm{pH}$, antioxidant, agitation and light on betacyanin stability using red-fleshed dragon fruit (Hylocereus polyrhizus) juice and concentrate as models. J. Food Sci. Technol. 2015, 52, 3086-3092. [CrossRef]

28. Serris, G.S.; Biliaderis, C.G. Degradation kinetics of beetroot pigment encapsulated in polymeric matrices. J. Sci. Food Agric. 2001, 700, 691-700. [CrossRef]

29. Herbach, K.M.; Stintzing, F.C.; Carle, R. Stability and color changes of thermally treated betanin, phyllocactin, and hylocerenin solutions. J. Agric. Food Chem. 2006, 54, 390-398. [CrossRef]

30. Herbach, K.; Stintzing, F.; Carle, R. Betalain Stability and Degradation-Structural and Chromatic Aspects. J. Food Sci. 2006, 71, 41-50. [CrossRef]

31. Herbach, K.M.; Rohe, M.; Stintzing, F.C.; Carle, R. Structural and chromatic stability of purple pitaya (Hylocereus polyrhizus [Weber] Britton \& Rose) betacyanins as affected by the juice matrix and selected additives. Food Res. Int. 2006, 39, 667-677. [CrossRef]

32. Martins, N.; Roriz, C.; Morales, P.; Barrosa, L.; Ferreira, I. Coloring attributes of betalains: A key emphasis on stability and future applications. Food Funct. 2017, 8, 1357-1372. [CrossRef]

33. Flores-Mancha, M.A.; Renteria-Monterubio, A.L.; Sanchez-Vega, R.; Chavez-Martinez, A. Structure and stability of betalains. Investig. Cienc. 2019, 44, 318-325.

34. López, A.; Deladino, L.; Navarro, S.; Martino, M. Encapsulation of bioactive compounds with alginates for the food industry. Aliment. Cienc. y Tecnol. Aliment. 2012, 10, 18-27.

35. Vergara, C.; Saavedra, J.; Sáenz, C.; García, P.; Robert, P. Microencapsulation of pulp and ultrafiltered cactus pear (Opuntia ficus-indica) extracts and betanin stability during storage. Food Chem. 2014, 157, $246-251$. [CrossRef] [PubMed] 
36. Xue, F.; Li, C.; Liu, Y.; Zhu, X.; Pan, S.; Wang, L. Encapsulation of tomato oleoresin with zein prepared from corn gluten meal. J. Food Eng. 2013, 119, 439-445. [CrossRef]

37. Luna-Guevara, J.; López-Fuentes, J.; Jiménez-Gónzalez, O. Microencapsulation of some bioactive compounds through spray drying. Rev. Iberoam. las Ciencias Biológicas y Agropecu. 2016, 5, 1-16. [CrossRef]

38. Parra-Huertas, R. Food Microencapsulation: A Review. Rev. Fac. Nac. Agric. Medellin 2011, 63, 5669-5684.

39. Flores-Belmont, I.; Jiménez-Munguía, M. Microencapsulation of active compounds with chitosan. Temas Sel. Ing. Aliment. 2013, 7, 48-56.

40. Arrazola, G.; Herazo, I.; Alvis, A. Microencapsulation of Eggplant Anthocyanins (Solanum melongena L.) by Spray Drying and Evaluation of its Color Stability and Antioxidant Capacity. Inf. Tecnológica 2014, 25, 31-42. [CrossRef]

41. Gallo-Nunura, M.; Cevallos-Vera, M. Comparative study of the dehydration of aguaymanto (Physalis peruvianum) by atomization and lyophilization using encapsulating agents in the retention of vitamin C. Repos. Univ. Nac. Pedro Ruiz Gallo. 2014. Lambayeque. Available online: http://repositorio.unprg.edu.pe/ bitstream/handle/UNPRG/115/BC-TES-3840.pdf?sequence=1\&isAllowed=y (accessed on 23 November 2020).

42. Manjunatha, S.S.; Raju, P.S. Rheological characteristics of reconstituted spray dried beetroot (Beta vulgaris L.) juice powder at different solid content, temperatures and carrier materials. Int. Food Res. J. 2015, 22, 2333-2345.

43. Diaz, Y.L.; Torres, L.S.; Serna, J.A. Effect of Encapsulation in Drying by Atomization of Biocomponents of Yellow Pitahaya with Functional Interest. Inf. Tecnológica 2017, 28, 23-34. [CrossRef]

44. Azeredo, H.; Santos, A.; Souza, A.; Mendes, K.; Andrade, M.I. Betacyanin stability during processing and storage of a microencapsulated red beetroot extract. Am. J. Food Technol. 2007, 2, 307-312. [CrossRef]

45. Pitalua, E.; Jimenez, M.; Vernon-Carter, E.J.; Beristain, C.I. Antioxidative activity of microcapsules with beetroot juice using gum Arabic as wall material. Food Bioprod. Process. 2010, 88, 253-258. [CrossRef]

46. Gandía-Herrero, F.; Cabanes, J.; Escribano, J.; García-Carmona, F.; Jiménez-Atiénzar, M. Encapsulation of the most potent antioxidant betalains in edible matrixes as powders of different colors. J. Agric. Food Chem. 2013, 61, 4294-4302. [CrossRef]

47. Janiszewska, E. Microencapsulated beetroot juice as a potential source of betalain. Powder Technol. 2014, 264, 190-196. [CrossRef]

48. Ravichandran, K.; Palaniraj, R.; Min, N.; Thaw, M.; Gabr, A.M.M.; Ahmed, A.R.; Knorr, D.; Smetanska, I. Effects of different encapsulation agents and drying process on stability of betalains extract. J. Food Sci. Technol. 2014, 51, 2216-2221. [CrossRef]

49. Antigo, J.L.D.; Bergamasco, R.D.C.; Madrona, G.S. Effect of ph on the stability of red beet extract (Beta vulgaris L.) microcapsules produced by spray drying or freeze drying. Food Sci. Technol. 2017. [CrossRef]

50. Omae, J.M.; Goto, P.A.; Rodrigues, L.M.; Santos, S.; Paraiso, C.M.; Madrona, G.S.; Bergamasco, D.C. Beetroot Extract Encapsulated in Inulin: Storage Stability and Incorporation in Sorbet. Chem. Eng. Trans. 2017, 57, 1843-1848. [CrossRef]

51. Guevara-Breton, N.A.; Jimenez-Munguia, M.T. Materiales utilizados en la encapsulacion. Temas Sel. Ing. Aliment. 2008, 2, 22-27.

52. Araujo-Diaz, S.; Leyva-Porras, C.; Aguirre-Bañuelos, P.; Alvarez-Salas, C. Evaluation of the physical properties and conservation of the antioxidants content, employing inulin and maltodextrin in the spray drying of blueberry juice. Carbohydr. Polym. 2017, 167, 317-325. [CrossRef]

53. Azeredo, H.M.C. Encapsulação: Aplicação a tecnologia de alimentos. Aliment. e Nutr. 2005, 16, 89-97. [CrossRef]

54. Madene, A.; Jacquot, M.; Scher, J.; Desobry, S. Flavour encapsulation and controlled release-A review. Int. J. Food Sci. Technol. 2006, 41, 1-21. [CrossRef]

55. Castro-Muñoz, R.; Barragán-Huerta, B.; Yáñez-Fernández, J. Use of gelatin-maltodextrin composite as an encapsulation support for clari fi ed juice from purple cactus pear (Opuntia stricta). LWT-Food Sci. Technol. 2015, 62, 242-248. [CrossRef]

56. Obón, J.M.; Castellar, M.R.; Alacid, M.; Fernández-lópez, J.A. Production of a red-purple food colorant from Opuntia stricta fruits by spray drying and its application in food model systems. J. Food Eng. 2009, 90, 471-479. [CrossRef]

57. Saénz, C.; Tapia, S.; Chávez, J.; Robert, P. Microencapsulation by spray drying of bioactive compounds from cactus pear (Opuntia ficus-indica). Food Chem. 2009, 114, 616-622. [CrossRef] 
58. Sánchez, F.D.; Maria, E.; López, S.; Kerstupp, S.F.; Ibarra, R.V.; Scheinvar, L. Colorant extract from red prickly pear (Opuntia lasiacantha) for food application. J. Environ. Agric. Food Chem. 2006, 5, 1130-1337.

59. Mensink, M.A.; Frijlink, H.W.; Maarschalk, V.; Hinrichs, W.L.J.; Polymers, C. Inulin, a flexible oligosaccharide I: 2 Review of its physicochemical characteristics. Carbohydr. Polym. 2015, 130, 405-419. [CrossRef]

60. Ruiz-Gutiérrez, M.G.; Amaya-Guerra, C.A.; Quintero-Ramos, A.; Pérez-Carrillo, E. Physicochemical properties of cereal pigmented with red prickly pear powder. Investig. y Desarro. en Cienc. y Tecnol. Aliment. 2016, 1, 710-716.

61. Altan, A.; McCarthy, K.L.; Maskan, M. Effect of extrusion cooking on functional properties and in vitro starch digestibility of barley-based extrudates from fruit and vegetable by-products. J. Food Sci. 2009, 74. [CrossRef]

62. Rodriguez-Sandoval, E.; Lascano, A.; Sandoval, G. Influence of Partial Substitution of Wheat Flour by Quinoa and Potato Flour on Thermomechanical and Dough Baking Properties. Artic. Cient. 2012, 15, 199-207.

63. Cui, S.W.; Nie, S.; Roberts, K.T.; Food, G. Functional Properties of Dietary Fiber, 2nd ed.; Elsevier B.V.: Amsterdam, The Netherlands, 2011; Volume 1.

64. Ferreira-Cardoso, F.; Ramirez-Ascheri, P.D.; Piler De Carvalho, C.W. Rheological and water adsorption properties of extruded rice flour and barley bagasse. Rev. Ceres Viçosa 2014, 61, 313-322.

65. Rashid, S.; Rakha, A.; Butt, M.S.; Asgher, M. Physicochemical and techno-functional characterization of inulin extracted from chicory roots and Jerusalem artichoke tubers and exploring their ability to replace the fat in cakes. Prog. Nutr. 2018, 20, 191-202. [CrossRef]

66. Ruiz-Gutiérrez, M.G.; Amaya-Guerra, C.A.; Quintero-Ramos, A.; Ruiz-Anchondo, T.D.J.; Gutiérrez-Uribe, J.A.; Baez-González, J.G.; Lardizabal-Gutiérrez, D.; Campos-Venegas, K. Effect of Soluble Fiber on the Physicochemical Properties of Cactus Pear (Opuntia ficus indica) Encapsulated Using Spray Drying. 2014, 23, 755-763. [CrossRef]

67. Cai, Y.; Corke, H. Production and Properties of Spray - dried Amaranthus Betacyanin Pigments. J. Food Sci. 2000, 65, 1248-1252. [CrossRef]

68. von Elbe, J.H.; SY, S.H.; Maing, I.Y.; Gabelman, W.H. Quantitative analysis of fetacyanins in red table beets (Beta vulgaris). J. Food Sci. 1972, 37, 932-934. [CrossRef]

69. von Elbe, J.H. The Betalaines; Furia, E.T., Ed.; CRC Press Inc.: Boca Raton, FL, USA, 1977; pp. $29-39$.

70. Delgado-Vargas, F.; Jiménez, A.R.; Paredes-López, O. Natural Pigments: Carotenoids, Anthocyanins, and Betalains-Characteristics, Biosynthesis, Processing, and Stability. Crit. Rev. Food Sci. Nutr. 2000, 40, 173-289. [CrossRef] [PubMed]

71. Azeredo, H.M.C. Betalains: Properties, sources, applications, and stability-A review. Int. J. Food Sci. Technol. 2009, 44, 2365-2376. [CrossRef]

72. Castillo-Garrido, I.C. Stability of betalains in a dry mix for refreshing beverages, based on microencapsulated pulp and extract of purple prickly pear (Opuntia ficus-indica). Repos. Univ. Chile 2013. Available online: http://repositorio.uchile.cl/bitstream/handle/2250/113994/castillo_ic.pdf?sequence=1\&isAllowed=y (accessed on 23 November 2020).

73. Yousefi, S.; Emam-djomeh, Z.; Mousavi, S.M. Effect of carrier type and spray drying on the physicochemical properties of powdered and reconstituted pomegranate juice (Punica Granatum L.). J. Food Sci. Technol. 2011, 48, 677-684. [CrossRef]

74. Valencia-Avilés, E.; Ignacio-Figueroa, I.; Sosa-Martínez, E.; Bartolomé-Camacho, M.C. Polyphenols: Antioxidant and toxicological properties. Rev. la Fac. Ciencias Químicas 2017, 16, 15-29.

75. Wang, H.Y.; Qian, H.; Yao, W.R. Melanoidins produced by the Maillard reaction: Structure and biological activity. Food Chem. 2011, 128, 573-584. [CrossRef]

76. Anderson, R.A.; Conway, H.F.; Peplinski, A.J. Gelatinization of Corn Grits by Roll Cooking, Extrusion Cooking and Steaming. J. Cereal Sci. Today 1970, 22, 130-135. [CrossRef]

77. Ahmed, M.; Akter, M.S.; Eun, J.B. Impact of $\alpha$-amylase and maltodextrin on physicochemical, functional and antioxidant capacity of spray-dried purple sweet potato flour. J. Sci. Food Agric. 2010, 90, 494-502. [CrossRef] [PubMed]

78. Xu, B.J.; Chang, S.K.C. A comparative study on phenolic profiles and antioxidant activities of legumes as affected by extraction solvents. J. Food Sci. 2007, 72. [CrossRef] [PubMed]

79. Singleton, V.; Rossi, J. Colorimetry of total phenolics with phosphomolybdic-phosphotungstic acid reagents. Am. J. Enol. Vitic 1965, 16, 144-158. 
80. Thaipong, K.; Boonprakob, U.; Crosby, K.; Cisneros-Zevallos, L.; Hawkins Byrne, D. Comparison of ABTS, DPPH, FRAP, and ORAC assays for estimating antioxidant activity from guava fruit extracts. J. Food Compos. Anal. 2006, 19, 669-675. [CrossRef]

81. Bradford, M.M. A Rapid and Sensitive Method for the Quantitation Microgram Quantities of Protein Utilizing the Principle of Protein-Dye Binding. Anal. Biochem. 1976, 254, 248-254. [CrossRef]

Sample Availability: Samples of the compounds are not available from the authors.

Publisher's Note: MDPI stays neutral with regard to jurisdictional claims in published maps and institutional affiliations.

(C) 2020 by the authors. Licensee MDPI, Basel, Switzerland. This article is an open access article distributed under the terms and conditions of the Creative Commons Attribution (CC BY) license (http://creativecommons.org/licenses/by/4.0/). 